\title{
Development of Local Wisdom-Based Tourism
}

\author{
Nabbilah Amir \\ Faculty of Law \\ University of Surabaya \\ Surabaya, Indonesia \\ nabila.amir@ubaya.ac.id
}

\begin{abstract}
This study aims to identify and identify strategies for strengthening local wisdom for people around tourist sites. Using empirical law research method and method approach case (case approach). The several strategies that are carried out in strengthening local wisdom include strengthening the local regulations of the city of stone. The results of this study indicate that the strategy undertaken to strengthen local wisdom is to apply local regulations based on local wisdom in the city of stone. So that the output of this research can be applied by local government in strengthening local wisdom which affirmed in regulation of area at stone town of east java province.
\end{abstract}

Keywords - investment; local wisdom; local regulation

\section{INTRODUCTION}

Indonesia is a Tourist Destination (DTW) with a list of very many attractions from Sabang to Merauke. Since it opened wide in 1967 investment in the tourism sector showed an intensive development. Until the year 2017 tourism sector made a new spearhead of government in the investment in Indonesia. Tourism object will be closely related to the investor, where there is an interesting area to become the object of tourism, then the area will be ogled the investors to invest their capital either in the form of tourism object management, hotel establishment, restaurant establishment or other matters related with facilities that support tourism. Investment that has grown rapidly and managed to raise his business, will invite interest of other investors to invest in the same area.

The tourism sector has a very important role for the main government in the sector of income increase both region and country, with the hope that the tourism sector can become a pillar of the economy in Indonesia as the target Ministry of Tourism is described in the Minister of Tourism Regulation no. 29 of 2015 on the Strategic Plan Kemeterian Tourism Year 2015-2019. One of the government's efforts in increasing the number of foreign tourists is also done with the establishment of Visit Indonesia Tourism Office (VITO) in several countries. Given the tourism sector has an important role in local revenue can be seen through the economic equity in the community that does not occur inequality between one areas with other regions. One example of a highly developed tourism sector in Indonesia, namely Batu City East Java Province, where Batu has a tourist attraction that is very much and become a tourist destination of local and foreign tourists. Since becoming an independent city, Batu City is increasingly showing improvement of its economy through the tourism sector.
Batu Town as a new city that has a brand image as a tourist destination city, as its Vision "Batu City Center of Organic Agriculture Based on International Tourism". Implementation can be seen through the number of tourism places in the city of Batu. Attractions in the city of Batu is a tourist attraction that is naturally formed and artificial tourist attraction in the city of stone, among others, Apus Kusuma Apples Tour, East Java Park 1, 2 \& 3, Batu Night Spectacular, Select a recretional Park and others. Establishment of Batu City as a tourism destination city will facilitate the investors in terms of investing capital which resulted in the development of tourism in the city of Batu is growing rapidly and make the city of Batu as a city that has the Object Attraction (ODTW), thus opening the wide promotion of tourism in Stone Town to the whole world.

The development of tourism objects in Batu Town today has slowly eroded local wisdom to the community where before the development of tourism object of the local community more have jobs as farmers and have strong local wisdom on agriculture world, such as Earth Alms, Kosokan and Rempes. These activities are characteristic of Batu Stone people to be grateful for the blessings of God at the time of harvest and post-harvest. However, the habit of gambokan and rempes gradually faded away because the community is more interested in the profession as a workforce or as a micro business actor in the field of tourism. Not to mention, traditional farming activities are slowly being replaced by more modern activities in the agricultural world.

As previous research written by Agus Sudaryanto which gives an affirmation of the strengthening of the value of local wisdom in the Management of Waterfall Sri Gethuk that has been proved using the foundation of the value of locality in making policies or rules. In this Sri Gethuk tour the managers and citizens involved in the service of tourists in this region are limited only citizens who live in Bleberan Village [1]. And other specific studies discussing regional government policies in capital investments by Subadi and Tiara Oliviarizky Toersina that provide Discretion for accelerated investment in the region, are integral to the development or empowerment and potential utilization in the region. The authority to administer investment or investment for its scope within a regency / municipality becomes the affairs of the regency / municipal government, while the implementation of investment with the scope of inter-regency / municipality becomes the affairs of the provincial government [2]. 


\section{METHOD}

Based on the predecessor's research, the writer wants to give the differentiation category in the research of Tourism Development based on the local wisdom with the case study in Batu City East Java Province is on the object of study which come from Batu Town which is a very developed tourism area in the field of tourism in East Java Province. The development of tourism is not supported by the strengthening of local wisdom in the local community. The local government prioritizes the improvement of the regional economy through the development of artificial tourism objects compared with the strengthening of local people's wisdom so that in a fairly short period of time after the determination of Batu Town as an administrative city to change the mindset of people who originally work as farmers into private labor on tourism objects or traders local on the tourism object.

\section{RESULT AND DISCUSSION}

\section{A. The Role of Regional Regulations in the Tourism Sector}

"Where there is sugar, there is an ant" This phrase is equated with where there is tourism object where investors flock to come to make investment in the tourism area. The tourism sector is one of the goals of investors to invest, considering the modern era of world society is no longer shy to travel tourism even though it must travel a considerable distance and spend a lot of money.

Investment both Domestic Investment (PMDN) and Foreign Investment (PMA), has a strong role to the economic climate in a region one of them in Kota Batu in East Java Province. Investment plays an important role in increasing local revenue, contributing to the introduction of technology, skills, management and opening up new jobs for local communities. The opening of new job opportunities gives people the opportunity to work in the business field invested by investors such as hotels, restaurants etc. People can also innovate open their own business field such as selling typical products of the region consisting of souvenirs or snacks typical of the area of tourism objects of quality and has a charm that becomes a tourist destination. In addition, investment in the tourism sector can also be a step development of tourism object promotion in terms of information and infrastructure.

According to Phil Janianto Damanik, there are several common threads of tourism development that are oriented towards the welfare of the community. First, the implementation of the strategy of expanding the business opportunity for the poor around the tourism area. Both expand employment opportunities for local residents. Third, the prevention of environmental quality degradation that has direct and more vulnerable impact on the community. Fourth, the emphasis is on minimizing the socio-cultural impact of tourism. Fifthly, the assistance of local communities for the development of core business and tourism supporters. Sixth, promotion of local organizations established for the benefit of tourism [3].

The growth of tourism sector in Batu City through its actual investment can be enjoyed by all the people around the tourism object and it should be able to grow continuously so as to make people prosperous. Through investment, the government of Batu City strives for the tourism objects of Batu City can be managed optimally so that the potential to introduce Batu City to the world. However, in this case the government tends to open a new tourism object in the form of artificial tourism, one of the development of tourism object in Kota Batu which is a pilot is Jatim Park 1. In the object of tourism Jatim Park 1, the tourists can find modern play rides with various facilities there is. The management of East Java Park 1 also provides a place for singing and hunting souvenirs typical of East Java Park 1. This facility is managed in conjunction with the surrounding community, the community who runs the hunting souvenirs typical of East Java Park 1 even given management training in entrepreneurship. Observing the management of Jatim Park 1, it can be seen that the role of investors in the implementation of tourism in East Java Park 1 can be said to successfully develop the community around the tourism object that has been running in recent years.

The problems later arising from the rise of investment in the artificial tourism sector such as East Java Park 1 shifted local local interest to the work that was involved, the people of Batu City mostly work as farmers today shifted to the profession of traders and private employees of tourism objects that impact on the scour local wisdom of local people who were initially very strongly associated with agriculture.

\section{B. The Relation of Tourism Organizer with Regional Regulation}

Investment of a region will certainly be closely linked with the local government, especially in the tourism sector, every investor in the tourism sector as a tourism organizer is obliged to comply with all laws and regulations applicable in Indonesia, in general the law no. 25 of 2007 concerning Capital Investment which provides investment procedures, rights and obligations for every Investment in Indonesia etc. [4]. In particular, investment in Indonesia is regulated in a Regional Regulation (Perda) on each of the areas that are the investment objectives.

Harmonious coordination among various institutions related to the effectiveness of the legal system, will work well if there is clarity of the main tasks and functions and authority of each institution, so that there is no duplication and even conflict. This is because the coordination function is related to the clarity of the integrated service pattern as well as the division of labor and authority between the central and regional governments. Therefore, it is necessary to have a coordination mechanism that is understood and binding for related institutions, for example concerning the issue of investment promotion, licensing, investment facility and others [5].

Batu Town is known as one of the leading tourist city in Indonesia because of its extraordinary natural beauty potential. The Dutch admiration for the beauty and natural beauty of Batu makes the Stone City area aligned with a country in Europe that is Swiss and dubbed as De Kleine Zwitserland or Small Switzerland on the Island of Java Together with the City of Malang and Malang Regency, Batu Town is part of a known territorial unity with Malang Raya (Metropolitan Region of Malang). 
As a fertile mountainous area, Batu and its surroundings also have a beautiful natural scenery and cool air, of course this will attract other people to visit and enjoy Batu as a mountain region that has its own charm. For this reason at the beginning of the 19th century Stone developed into a tourist destination, especially the Dutch people, so that the Dutch people helped build the resorts (villas) and even settled in Batu. (Www.kotabatu.go.id)

The beauty of Stone Town to realize the government to be able to exploit the potential of Batu City in terms of tourism. Tourism development in Batu City is a plan that has been made since Batu became City Government since 2001. Tourism policies in the future can adopt previous policies and provide new innovations aimed at building tourism in Batu Town. Latest, the government pours in the Vision of the City of Batu that is "City of Center-based Sentra Organic Agriculture International Tourism" [6].

Tourism-related arrangements as a basis for strengthening the vision of Batu City can be seen in Local Regulation No. 4 of 2004 on the Function of Batu City and Regional Regulation of Batu City [7]. 1 of 2013 on the Implementation of Tourism [8]. Furthermore, the Regional Regulation which also sustains the Vision of Batu City which has International Tourism base is also regulated in Article 6 of Batu City Regional Regulation No. 7 Year 2011 on Spatial Plan of Batu City Area Year 20102030 [9].

The policy on tourism in Batu Town is regulated in Batu City Regulation with the consideration that there is no overlapping of central and regional government regulations. As in Batu City Regulation No. 4 of 2004 on the function of the City of Stone that is as the City of Agriculture and Tourism City [7]. As an Agricultural City (agropolitan), its development is directed to integrated agricultural development activities where physical, socio-cultural and economic conditions tend to be strong and lead to agricultural activities. As a tourism city of Batu City tourism development which includes the development of attractions and attractions, the development of tourism services business, the development of tourist service center, the development of tourist information center.

Observing the development of Batu City tourism is significantly uphill, the government of Batu City issued a related arrangement of tourism in Kota Batu regulated in the Regional Regulation No. 1 of 2013 on the Implementation of Tourism in Batu City [8]. The supporting facilities in detail are set forth in Article 6, explaining that "tourism business consists of tourism attraction business, tourism area, tourism transportation service business, travel service business, food and beverage business, accommodation provider business, entertainment and recreation, meeting business ventures, incentive trips, conferences and exhibitions, travel information services business, tourism consultant services and tour business. Capital investment in tourism support business is also experiencing a very rapid growth so that tourists increasingly glance at Batu Town as a Tourist Destination (DTW). Furthermore, Batu City Government also provides reinforcement to Batu City Regulation No. 1 of 2013 with the existence of perda that has been issued previously namely Regulation No. 7 of 2011 on Spatial Planning (RTRW Kota
Batu). With the Spatial Plan of Batu City Region which is devoted to tourism and agriculture that regulate the city order in the placement of natural tourism location, artificial tourism and agriculture.

\section{Relationship of Local Regulations with Local Wisdom}

Local wisdom is described as habits, values, norms, rules that are adhered to in social life in a region or in a certain place that has been going on for generations and become a habit in the life of society. This can be reviewed based on three aspects of the domain of local wisdom, namely, the first relationship between man and man, the two human relationships with nature, the three human relationships with the creator. Uniquely, local wisdom that exist in the midst of society, especially in Indonesia will be different from one area to another. This is because the development of local wisdom has been going on for a long time and became the ancestral heritage of each region.

Etymologically, local wisdom consists of two words: wisdom (local) and local (wisdom). At KBBI, local meaning local, as well as wisdom is the same as wisdom. Thus, if viewed etymologically, local wisdom can be interpreted as local ideas (wise), wisdom, good value, embedded and followed by members of the community [10].

The term local wisdom was first introduced by HG. Quaritch Wales which mentions local wisdom as "local genius" which means a number of cultural traits shared by a society as a result of its past experience. Yunus interpreted local wisdom as a culture owned by certain people and in certain places that are considered mamp to survive the flow of globalization, because the local wisdom contains values that can be used as a means of building the character of the nation [10].

Local Wisdom in an area will always be closely related to the local community culture downhill which is done by people who believe it so that makes it a habit in everyday life. Local wisdom is a fusion of the sacred values of God's word and various values. Local keripan formed as a cultural superiority of local communities and geographical conditions in a broad sense [11]. Local wisdom begins with ideas or ideas, which are then applied in the stages of practice, and the creation of cultural forms. The factors include several things namely language, belief / religion / belief, education, economy and art. The general view of local wisdom within a region is a longstanding view of life that has been run by local communities and is a fulfillment of problem solving within the community. Local wisdom that became the attraction of tourism becomes an important thing to be developed so that the values of ancestors that are embedded and become a culture in a region remain intact implemented as should have been run by indigenous people. The customary community alliance is volksgemeen-scappen, which has its own social system and has a strong relationship with the land, the management of its natural resources, and has the discretion to retain local values or local wisdom [12].

In the context of community development that has implications for the tourism sector, it provides a paradigm of thinking in the development of a culture consisting of four components: 
- Preserving and Appreciating Local Culture. Tradition of local culture is an important part in instilling a sense of community, and provide identity to the community. Communities need to identify what the unique components of their cultural heritage are, and determine which components to sustain. All of that requires structured planning, as well as achieving it. For example, building local industries based on local culture.

- Preserving and Respecting Indigenous Cultures. Preserving and appreciating the culture of indigenous peoples is a central issue for community development. Indigenous or indigenous peoples whose members dominate and therefore the community is identified, as well as cases of indigenous people who belong to a society and people of different cultural backgrounds.

- Multiculturalism. In general, multiculturalism refers to different ethnic groups living in a community but retaining different cultural identities. The issue of multicultural and political policy is very complex, but the diversity of cultural backgrounds is a reality for many societies. Therefore, multiculturalism is an important aspect of community cultural development [13].

Focus on the local wisdom that began eroded its existence in the city of Batu, impact on the values of the local community, Previously, before the City of Batu filled with artificial tourism as today, people who work as farmers have a habit ahead of Idul Fitri holiday that is carrying out ritual kosokan where people fulfill the public baths for cleaning the lobes (mud attached) on their feet and hands using leaf lamtoro, so that the return is clean and sacred before Idul Fitri holidays conducted on one of the natural public baths in Batu Town known as Blumbangan Macari. As time passes, rock city communities are more likely to leave agriculture and switch professions to the world of trade and private employers of tourism these habitual habits no longer become a habit of local communities. Not only that, apple farming that was forced to industrialization of artificial tourism in Kota Batu also resulted in the erosion of the culture of rampes, which is to examine the post-harvest apple leaves that are done together from one field to another with different owners. Lately, this activity has been replaced by spraying pesticides pesticide apple leaves so that the leaves will dry and will fall off by itself. Observing the scouring of local wisdom in society due to the increase of artificial tourism sector, the strengthening of the elements of local wisdom in local regulations where the government provides strengthening local people's understanding of the importance of existing local wisdom as a manifestation of the customs of rock town society. In addition, the government should also strengthen local wisdom in the city of stone through investment regulations that must be implemented by investors amid the modernization flow in Batu City.

One form of arrangement that every investment process in Indonesia requires investors to carry out corporate social responsibility, respecting the traditions and culture of the communities surrounding the location of investment business activities and complying with all the provisions of legislation as regulated in Article 15 letter d Law No. 25 Year 2007 about the investment that gives an explanation that is "Respect the cultural traditions of the community around the location of investment business activities" [4].

In general, the obligations for every investor in Indonesia, both for domestic investors and for foreign investors. Furthermore, arrangements related to investment in tourism sector are also regulated in Local Regulation no. 1 of 2013 Article 5 letters a and b, Article 66 letter a and Article 76 which repeatedly affirm that all investors must respect and uphold local wisdom in Batu City [8]. The local forms of wisdom in the city of Batu namely Kosokan, Rempes, Alms Earth and Clean activities of the Village which has become a habit of the people of Batu Town from generation to generation. Then, other Batu City culture that fulfill the elements of art, such as warokan, jaran braid, bantengan, dance sembromo, dance ledrek, ketroprak, ludruk, wayangan, art of hadra, flying jidor dll. When reviewing Regulation No. 1 Year 2013 local wisdom of Batu City must be highlighted on the efforts of investment, especially tourism in the city of Batu.

The strengthening of local wisdom that is emphasized in the Local Regulation will have a close relationship. As explained in the previous explanation, that investors are required to comply with the prevailing laws and regulations in Indonesia and in the City where the investment will take place. The subordination of investors to legislation should be able to implement everything that is done for the development of its business must uphold the existing local wisdom. As in Kota Batu which has local wisdom, it should be in the business activities in tuck the elements of local wisdom. For example, in Kota Batu at the ceremony of alms, reviving traditions and / or traditions rempes the role of investors can be seen through the exploration of these activities on his business and can be made a form of promotion to people outside Batu Town without reducing the values of local wisdom, so that people not only see the city of Batu not just lift the tourist attraction but also still hold the local wisdom.

\section{CONCLUSION}

Based on the above description it can be concluded that, the role of local regulations in the development of local wisdombased tourism is very strong. Where local governments as giver, executor and policy controllers should be able to inhibit the shift of local wisdom community that characterizes the city of Batu. In fact, local governments in this case become unifying and upholding local wisdom in the development of tourism as the identity of the city of stone amid growing investment in the tourism sector through specific regional regulations regulating the existence, strengthening and preservation of local wisdom stone city. Furthermore, in the development of tourism sector investors are required to be able to preserve and strengthen the element of local wisdom in the field of business that run, it is as mandated in the Perda Batu City. 1 of 2013 Article 5 letters a and b, Article 66 letter a and Article 76 which repeatedly affirm that all investors must respect and uphold local wisdom in Batu City so that this regulation is not abstract [8]. 


\section{ACKNOWLEDGEMENT}

The author would like to thank all the parties who have helped and contributed in the writing of this article, both those who contribute in the form of funding and critical ideas. Hopefully this paper can be useful theoretically and practically for the addition and development of knowledge, especially in the field of legal science.

\section{REFERENCE}

[1] S. Agus. "Nilai-nilai Kearifan Lokal yang Diterapkan dalam Pengelolaan Tanah Pariwisata Sri Gethuk di Bleberan, Playen, Gunung Kidul." Mimbar Hukum-Fakultas Hukum Universitas Gadjah Mada 30.1: 78-93. 2018.

[2] S. Subadi, and Tiara Oliviarizky Toersina. "Perkembangan Konsep atau Pemikiran Teoritik Tentang Diskresi Berbasis Investasi di Daerah." Mimbar Hukum-Fakultas Hukum Universitas Gadjah Mada 30.1: 17-31. 2018 .

[3] P. J. Damanik, Pariwisata Indonesia (Antara Peluang dan Tantangan, Yogyakarta, Pustaka Belajar, 2013.
[4] Undang-undang Nomor 25 Tahun 2007 tentang Penanaman Modal

[5] A. Rokhmatussa'dyah and Suratman, Hukum Investasi dan Pasar Modal, Jakarta, Sinar Grafika, 2011

[6] Pemerintah Kota Baru, Visi dan Misi, http://website.batukota.go.id/statis-2-visi-dan-misi 2010.

[7] Peraturan Daerah Nomor 4 tahun Tahun 2004 tentang Fungsi Kota Batu yakni Kota Pertanian dan Pariwisata.

[8] Peraturan Daerah Kota Batu Nomor 1 Tahun 2013 tentang Penyelenggaraan Kepariwisataan.

[9] Peraturan Daerah Kota Batu Nomor 7 Tahun 2011 tentang Rencana Tata Ruang Wilayah.Kota Batu Tahun 2010-2030.

[10] M. Maridi, Mengangkat Budaya dan Kearifan Lokal dalam Sistem Konservasi Tanah dan Air, Seminar Nasional XII Pendidikan Biologi, Vol 12, No 1, 2015.

[11] R. K. R. Hammar, Penataan Ruang Berbasis Kearifan Lokal, Calpulis, Yogyakarta, 2017.

[12] A. Saptomo, Hukum dan Kearifan Lokal ( Revitalisasi Hukum Adat Nusantara),Cikal Sakti, Jakarta,2010

[13] I. Jim and F. Tesoriero, Alternatif Pengembangan Masyarakat di Era Globalisasi, Community Development, Yogyakarta, Pustaka Belajar, 2008. 